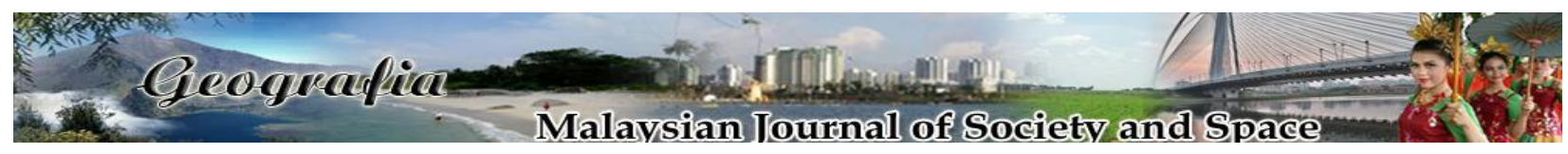

\title{
Kootu fund as saving scheme of B40 Malaysian Indian women: Insights behind the participation as players and organisers during Movement Control Order
}

\author{
Nithiya Guna Saigaran \\ School of Social Sciences, Universiti Sains Malaysia \\ Correspondence: Nithiya Guna Saigaran (email: nityaah@gmail.com)
}

Received: 26 April 2021; Accepted: 19 August 2021; Published: 27 August 2021

\begin{abstract}
Bottom 40 which was also known as the B40 households were the vulnerable group that mostly possessed setbacks in terms of finance, health, employment, skills, accommodation, time, and other significant life aspects. B40 households also hold lower socio-economic status among other household groups in Malaysia. Being the female counterparts in the impoverished households, these women faced various hurdles in terms of social, economic, and political perspectives. Malaysian Indians from the B40 group were depicted as the marginalised group in the urban areas. The vulnerability of the B40 women was undoubtedly in a worrying situation as they had the pressure to face the hurdles in the form of patriarchal underlined roles and responsibilities. In considering the B40 group, various financial assistance is being initiated by the Malaysian government. Malaysians have started to create the effort to cope with their household's impoverishment among themselves and their households. Having said that, the 'Kootu' fund became an important effort among Malaysian Indians, especially among B40 Malaysian Indian women. Even though the 'Kootu' fund could not be regarded as stable savings that could empower the women's financial strength, it is somehow enlarging and creating the space for the Malaysian Indian women in terms of their various life aspects. Having said that, the factors behind their participation in Kootu fund were scantly available. Thus, this article intends to explain the factors behind B40 Malaysian Indian participation in the Kootu fund using their narratives regarding their experiences as players or organisers. In-depth interviews were conducted with fifteen B40 Indian women who were selected through snowball sampling around Sungai Karangan housing areas in Kulim, Kedah. The analysis revealed four main themes: motivation to participate economically within the setting of the household, to ease from patriarchal subordinated household roles, establish a networking system with peers around them, and accumulation of savings. The findings of this study would enlighten academicians, researchers and policy makers interested in understanding the reasoning and the complexity behind women participation in informal savings schemes such as Kootu Fund. The findings of the study imply that the Kootu fund does not merely act as a savings scheme, but it requires more intensive analysis to understand its benefits towards the B40 women.
\end{abstract}


Keywords: B40 women, Indian household, Kootu fund, Malaysian Indian women, patriarchy, savings, Sungai Karangan

\section{Introduction}

Kootu funds found to be used particularly by family members, amongst friends or within a small village during the 1960s and 1970s (Acams Today, 2011). Kootu fund is one method where specific amounts of money were pooled among certain group members, mostly relatives, and friends. The members who participate in the Kootu fund are known or called players (Rani, Hamit, Das, \& Shaikh, 2011). Malaysian Kootu Funds (Prohibition) Act 1971 revealed that Kootu funds mean:

'A scheme or arrangement variously known as Kootu, cheety, chit fund, hwei, tontine or otherwise such common fund is put up for sale or payment to the participants to subscribe periodically or otherwise to a common fund is put up for sale or payment to the participant by auction, tender, bid, ballot or otherwise, and includes any scheme or arrangement which with variations partakes of nature of a Kootu, cheetu, chit fund, hwei or tntine'....

[Kootu Fund (prohibition) Act 1971 (Act 28) (Kootu Act'), page 5-6]

Kootu fund was often criticised as the concept is not safe as a formal banking system and has risks such as missing insurance coverage, ceasing membership, and money-losing risks (Rani et al., 2011; Joremi, Zakaria, \& Abu Bakar, 2021). Having said this, the organisation of Kootu among trustable members such as family members would not be considered unlawful (Rani et al., 2011). However, some laws can be applied to the action against the individual if there is black money involved, advertised, earned interest, or charge a membership fee for the player's participation. Other than Act 28, the Rotating Savings and Credit Association (ROSCA) asserted that playing traditional Kootu fund among friends is legal; however, it could be considered illegal on two occasions; if the leader chargers membership charges for the joining or subscription of the participants in the Kootu fund and also Kootu leader claims profits from the participants for his or her own personal benefit (Bernama, 2021). In such cases, authorities can act against the individual using the AMLA (Anti-Money Laundering Act) to prosecute the involved individuals. Individuals and companies, and institutions will also be charged with misusing the concept for their benefits. The business premises would face closure of the business if their company or insitution were identified as having organised the Kootu fund (Rani et al., 2011). Kootu is most commonly 'played' with money raised from individual contributions. However, lately, items such as jewellery, make-up sets, kitchen utensils and cookware are often popularised in the Kootu fund. A fixed amount of money or items will be given monthly to each player regardless of money or material, depending on the commitment to the number of months and players. The organiser, who is also a participant, will most likely get the first payment or material. The others will receive according to their turn that they get selected from the balloting. The Kootu will end with the person year of receiving his or her amount of money and material. The Kootu fund is mostly popular among underprivileged community groups, as in Malaysia, those groups are identified as B40 groups.

B40 refers to the income group with lower wealth and non-financial asset ownership. They gravely depend on governmental and non-governmental organisations (NGOs) for survival and are very vulnerable to economic shocks (Malik \& Ayop, 2020). Currently, it is estimated that there 
are 2.7 million B40 households in Malaysia (Sakarji, Shari, Masnieza, \& Mustapha, 2021). The B40 households often have setbacks in terms of education, employment, and income, which push them to initiate efforts or be a part of the efforts that were undertaken by others to overcome their financial hurdles and prolong their sustainability. Kootu has been identified as the 'women' territory (Rani et al., 2011). Besides, the concept of Kootu has become a popular practice among homemakers in Malaysia (Rani et al., 2011). In the same vein, the money pool method, called Kootu, was identified as the most popular method among poor Indian women in Malaysia. In the lower socio-economic households like B40, women most often have to embrace traditional roles such as a housewife and caretaker of a family while their partners are away from home as breadwinners. Thus, the dependency is truly evident. These women often do not have a banking account, but were dependent on their husbands for income support, had no own employment, or were involved in lower-paid employment. These women actively involve themselves in the Kootu to solve the immediate money problems by involving themselves in the money pooling schemes. This study intends to investigate about the factors that influence the B40 women to participate in the Kootu and further explores how they manage their impoverishment. The exploration is significant to identify the active participation of poor Indian women in the Kootu. It is being identified as one of their significant initiatives in managing the impoverished life.

\section{Literature Review}

Kootu is regarded as one of the informal micro financing concept (Satkunasingam \& Shanmugam, 2006; Shanmugam, 1991); savings or free interest loan (Rani et al., 2011); cooperative endeavour (Omobowale, 2011; Rani et al., 2011; Shanmugam, 1991). It is regarded as one of the methods to save or pool money for an emergency. Often middle-income earners and lower-income earners prefer this method as an effort to do emergency savings or group savings that can be used as their immediate capital to solve immediate financial problems that surround their lives (Rani et al., 2011). Kootu fund amounts are often varied and often fixed by the fund organiser. Rani et al. (2011) asserted that the collection of fund amount involved in the Kootu fund depended on the player's affordability, and it would be from RM10 to RM1000 range. The fund organisers were the leaders of the Kootu fund, and they were the people responsible for collecting the Kootu and submitting it to the players (Joremi, Zakaria, \& Abu Bakar, 2021; Rani et al., 2011). Kootu was popularised among women from lower socio-economic backgrounds since they were unable to do the long-term savings in the official bank institutions due to various limitations. Informal savings become the preference for poor people due to various factors: on-hand cash availability for urgent times, and no bank interest (Oranu, Onah \& Nkhonjera, 2020; Kendall, 2012). The existence of Kootu was something under the scrutiny of criticisms due to the nature of the informality (Joremi, Zakaria, \& Abu Bakar, 2021). There is an informal financing system that exist among other communities similar to the Kootu fund. For instance, Rani et, al (2011) mentioned 'musyawarrah' or helping a person who is in need, an Islamic concept meant to assist the contributors to solve their financial problems and re-design the best option to settle loans that they borrow from the contributors. However, a significant difference occurs between Kootu and 'Musyawarah'. The Islamic perspective focused on welfare by providing assistance to the borrowers compared to the Kootu fund, which focuses more on the arrangements, and monetary and material benefits (Rani et al., 2011). 


\section{Method}

Snowball sampling was employed for this study. The first Kootu player was identified as the first participant after the researcher's initial networking with a person who suits the study's characteristics. Then, the following participants were identified from one player to another. A total of 15 participants were recruited for this study. In depth interview was used as qualitative method for this study. The other selection criteria of the participants include receiving mean household income of RM3299 (which classifies them to belong to the B40 group), and they were also identified as participating in the Kootu as the players or the organisers (leaders). Household income refers to both men and women income in the household. This study employed RM 3299 as mean household income of Indian households (Department of statistics, 2019). All the participants were selected from the Sungai Karangan housing areas in Karangan District in Kulim, Kedah. The participants were all married.

After the MCO implementation from July to December 2020, the participants were interviewed in their mother tongue, the Tamil language. In order to explore Kootu participation, questions were asked as follows: How long have you participated in Kootu? What are the minimum and maximum Kootu amounts played? Why are you involved in the Kootu fund, etc.). All the participants have been identified as participating or organising the Kootu among their family members and neighbours that they have known for the longest period of time and developed trustable relationships. This study employed narrative analysis as its methodology. The interview session was conducted in their households in the agreed time slot by the participants. All the interviews were recorded and transcribed in Tamil and translated to English. The interview transcripts were then coded using NVivo software. The reoccurring themes (i.e., accumulation of savings, establish a networking system with the peers around them) were identified and presented with the narrations as the qualitative findings of this study.

\section{Participant's characteristics of the study}

Table 1 shows the participant's name (pseudonym), age, working status, Kootu Fund (Minimum and Maximum amount), and the year of Kootu involvement. Based on the table, the majority of the participants are housewives. The remaining are contract workers, home food businesses, Indian ethnic wear vendors, breakfast vendors, and handmade jewellery vendors. All the participants belonged to the age group between 36 to 48 years old. In terms of Kootu fund involvement, six months is the lowest, and five years is the highest time duration. In terms of Kootu fund played, the minimum amount is RM1500, and the maximum amount is RM5000.

Table 1. Pseudonym, age, working status, Kootu fund (minimum \& maximum played amount), and the years of involvement in the Kootu Fund

\begin{tabular}{|c|c|c|c|c|c|c|}
\hline No. & Pseudonym & Age & $\begin{array}{l}\text { Working } \\
\text { Status }\end{array}$ & $\begin{array}{c}\text { Kootu Fund } \\
\text { [Minimum played } \\
\text { amount (RM)] } \\
\end{array}$ & $\begin{array}{c}\text { Kootu Fund } \\
\text { [Maximum played } \\
\text { amount }(\mathrm{RM})] \\
\end{array}$ & $\begin{array}{c}\text { Years of } \\
\text { Involvement in } \\
\text { the Kootu fund }\end{array}$ \\
\hline 1. & Durgamma & 45 & $\begin{array}{l}\text { Contract } \\
\text { worker }\end{array}$ & RM2000 & RM3000 & 3 years \\
\hline 2. & Indrani & 40 & Housewife & RM1000 & RM1000 & 2 years \\
\hline 3. & Ilavarasi & 39 & $\begin{array}{l}\text { Home food } \\
\text { seller }\end{array}$ & RM3000 & RM3000 & 1 year \\
\hline 4. & Jayarani & 42 & Housewife & RM2000 & RM2500 & 1 year \\
\hline
\end{tabular}




$\begin{array}{lllllll}\text { 5. } & \text { Parijatham } & 43 & \text { Housewife } & \text { RM3500 } & \text { RM4000 } & \text { 6 years } \\ \text { 6. } & \text { Kamatchi } & 37 & \text { Housewife } & \text { RM2500 } & \text { RM3000 } & \text { 2 years } \\ \text { 7. } & \text { Mages } & 36 & \text { Housewife } & \text { RM1000 } & \text { RM2000 } & \text { 4 years } \\ \text { 8. } & \text { Thevagi } & 37 & \text { Housewife } & \text { RM3000 } & \text { RM5000 } & \text { 5 years } \\ \text { 9. } & \text { Sreedevi } & 48 & \text { Housewife } & \text { RM2000 } & \text { RM3000 } & 3 \text { years } \\ \text { 10. } & \text { Anjalai } & 43 & \text { Housewife } & \text { RM2000 } & \text { RM2000 } & 3 \text { years } \\ \text { 11. } & \text { Yagini } & 38 & \text { Housewife } & \text { RM1500 } & \text { RM2500 } & \text { 2 years } \\ \text { 12. } & \text { Lalithambigai } & 42 & \text { Housewife } & \text { RM2000 } & \text { RM2000 } & 6 \text { months } \\ \text { 13. } & \text { Kaliamma } & 41 & \begin{array}{c}\text { Indian ethnic } \\ \text { wear seller } \\ \text { Breakfast }\end{array} & \text { RM3000 } & \text { RM4000 } & 4 \text { years } \\ \text { 14. Sivagami } & 41 & \text { RM1500 } & \text { RM1500 } & 6 \text { months } \\ \text { 15. Kannamma } & 45 & \begin{array}{c}\text { Handmade } \\ \text { jewellery } \\ \text { seller }\end{array} & \text { RM2000 } & \text { RM2500 } & 3 \text { years } \\ & & & & & \end{array}$

\section{Results and discussion}

Theme 1: Motivation to participate economically within the setting of the household

Economic participation is one of the factors that motivated women to get involved in the Kootu fund. About $75 \%$ of the participants expressed that they want to be economically active while holding the household roles. In the Kootu fund, these women are able to hold roles as organisers and participants. In this study, by being leaders or players, the Kootu gives the women power and authority to control and manage the group from the start till the completion of Kootu. These women felt empowered in the sense that they have the authority and leadership role in the scheme for the given time. Further to this, a participant named Durgamma explained as below:

'It is nice to do it....you know not everyone can handle this (Kootu), you need to have certain values to do it, like being responsible and lead everything from start to end...in terms of the Kootu, like me, I need to manage everything, from calling and gathering people, fixing the amount ... and balloting the turn of the Kootu players to collect the money... and also making sure the players paid the agreed sum of money at a fixed time without any delay or reason' (Durgamma, age 45)

Women from lower socio-economic backgrounds rarely got an opportunity to be involved in economic activities compared to their male partners. Their activities are often being confined in the household with no or limited power, authority, financial support, and empowerment. This study found out that participation in Kootu exposes the women to shift from the traditional roles towards embracing the men's roles occasionally. The participant's explanation showed that as the organiser of the Kootu, she leads, manages, and organises the players under her wing and also manages the money involved. Some of the participants explained that motivation to be involved in the Kootu funds' scheme was derived from the intention to operate themselves to solve the economic impacts caused by the Covid-19 pandemic. One of the participants, Indrani, a housewife whose husband is working as a technician in a construction company in a nearby industrial area, explained that:

'My husband is of a very orthodox kind, in his family, the women will not work, just stay as housewives...before marriage, they have already informed about this, but at that time I did not take it seriously, but after two years, I feel like there is too much dependency...I need to ask him for money for anything that I want to buy...sometimes he gives sometimes no...to some extent I feel annoyed, and I was thinking what is the 
solution for this, especially the corona issue, you realise the meaning of work and payment all...so that's why I started this Kootu thing...I feel like I'm working on something and get money and things out of it...it is better rather than spending much time in doing housework which pays you nothing...'. (Indrani, age 40)

Indrani's explanation showed that she had the interest to go to work and earn by herself. Her husband and traditional in-law family fixated her housewife status. This implicates that her interdependency was not a personal choice; however, she is bound to follow her qualities associated with her femininity that has been underlined by the husband as household breadwinner. She intended to be financially sound by having authority over income and have employment on her own. She felt that being the organiser of Kootu that involves money and things makes her transcend household roles and embark on the leadership roles even though it has occurred inside the household. Another participant, Ilavarasi, explained as below:

'...after this pandemic happened, my husband's salary got reduced and his working days cut short, at that time we were in some kind of debts, my sister introduced about the six months Kootu and suggested that I can be the second player...last year in August I got the money... after paying a small portion of the debt, the remaining I used as capital to start a home-cooked food delivery business, at first it was kind of slow, but now it's very hot business...'. (Ilavarasi, age 39)

Financial instability most commonly occurred in lower socio-economic households. The vulnerability of the women increased due to these shortcomings, such as the debts, loans, and borrowing that happens within the household. Ilavarasi also experienced the financial impact through her husband's salary cut in his company and was also surrounded by debts. She realised the importance of minimising the debts, increasing her savings, and participating in the Kootu fund as the player. The savings she accumulated through the Kootu became her savings to settle the debts and buy jewellery. The most significant benefit she gained from Kootu fund is she had initiated her home-cooked food delivery business, which could empower her financially to yield income for herself.

\section{Theme 2: To Ease from Patriarchal subordinated household roles}

The Kootu fund allows women to have a space for themselves and ease temporarily from the patriarchal roles. In this study, about $58 \%$ of the participants also acknowledged that they were interested in participating in the Kootu fund as it is a diversion from their patriarchal household roles. The majority of the participants were housewives, most likely to embrace the roles of mother, wife, and caretaker as their primary roles, and employment was regarded as secondary. The patriarchy system is the main factor for the role positioning in the hierarchical form of the men and women in the household (Ozdemir-Sarigil \& Sarigil, 2021; Kandiyoti, 1988). The patriarchal system allows them to operate within limited or sometimes with no power and authority to ensure the 'male supremacy' and 'women subordination' in the traditional households. Thus, these women are expected to manage household matters such as family health and nutrition, raising and bearing children, managing the household, and others (Jabeen et al., 2020). Another participant Parijatham expressed as below:

'...before marriage I was actively involved with my mom, had organised many Kootu...all among my cousins and relatives...it was fun at the same time as I used to spend my time to organise, plan and execute all... after marriage, I did not continue playing the Kootu... where will I have the time for this? Here day and night occupied 
with kids and husband...furthermore, I have to ask everything from my husband, once I asked to organize Kootu...he just ignored the matter altogether...but I didn't let my intention go...I just really needed break, from all this never-ending work...so after talking to my former players, mostly my relatives...I started to organise this Kootu...'(Parijatham, age 43)

The Kootu fund somehow pushes women to have a space and time for the women as players. They are distancing themselves from the household roles and responsibilities during the Kootu involvement. Parijatham's household situation very well reflected the personal time and individual space deficiency for her as a full-time housewife due to the accumulation of household work and the patriarchal system. Like Parijatham, women always have very limited space or sometimes no space based on the momentum of the patriarchal system in the family since the 'do' and 'don'ts' might be slightly different in the marginal of the patriarchy from one Indian household to another Indian household. The impact and influence of the patriarchy remained strongly in cocooning her inside the home in the form of limitations on women's freedom and their activities inside and outside of the household. Sometimes women's desires and wishes are ignored, like how the Parijatham's desire to venture into the Kootu fund and organising it was ignored by her husband, which reflects that the husband dislikes or has a disinterest in terms of his wife's participation in the Kootu. However, Parijatham strongly believes that she needs personal time and space and did not want to be sandwiched between the household roles and restrictions. Hence, she started to continue organising the Kootu fund. Most of the time, the woman will not be given or allowed access to the only and limited household resource, i.e., income. Kamatchi, a company operator, explained as below:

'I have heard about the Kootu from my friends in my workplace... a few of them are frequent Kootu players...now I'm playing Kootu with my sisters... At that time my husband used to take all my salary, leave nothing for me so at that time I decided I have to stop giving him ... above all the most worrying thing is I need to do this without my husband's acknowledgement...Because if he knows about it, everything will be ruined...but somehow I can manage to hide my Kootu involvement from him till now ...' (Kamatchi, age 37)

Working women in the B40 group did not have financial freedom despite them having paid work on their own. Since they were subordinates to the husband, they sometimes need to surrender their income to the husband since he is the household leader who is positioned as the household head. Like Kamatchi, the income of these women was forcibly taken by their husbands. Having experienced this disempowering situation in terms of income and time, these women found their involvement in the Kootu fund gave them the freedom they are looking to loosen themselves in the tight clutch of the patriarchy system.

\section{Theme 3: Establish a networking system with the peers around them}

The Kootu fund acts as a platform that has enabled these women to create a network or renew the network within various members inside and outside their households in this study. Consequently, $67 \%$ of the participants admitted that they develop networking with peers around them, such as their neighbours, siblings, and friends. In the lower socio-economic households, women are mostly confined in the house and likely to communicate and exercise their relationships within the household. 
'I am in charge of the Kootu to buy household things, like rice cooker, blender, and sometimes small jewellery like earrings...currently, I am doing Kootu on home dinner set.... so for that, I often visit my sisters, neighbours and cousin sister and other family members to talk about the Kootu and gather them...now I have my support group for Kootu, we always meet, discuss and chat with each other about the products and prices...' (Mages, age 36)

The involvement of counterparties in the local neighbourhood or social network is always significant in the informal savings system (Kendall, 2012). Mages' narration had explained how she established the network for the Kootu. For Kootu she moved around and maintained the connection with her relatives, friends, neighbours, and family. Not only to talk about the Kootu fund but also to share their problems, feelings with the people in their networks and find a solution for them. As Mages mentioned, a new support system was formed through the Kootu fund, which will be very beneficial for the women players. In this, the participants also revealed that the various life aspects have been improved through the networks that have been known through the Kootu fund. Participant named Thevagi detailed her experience as below:

'I am often confined at my home only, speak to my children and my husband...that is also very limited because my husband is away at work the whole day and my kids are busy with their studies...I often feel lonely, want to share my thoughts and feelings, especially to my sisters... we are very close to each other, after marriage, all of us felt so distant from each other...at that time, my elder sister proposed to me about the Kootu idea which later we (sisters) all agreed to do and we included our sisters-inlaw and our cousin sisters too...it was all women (she was laughing)...felt so nice, every day we send voice notes sharing all our thoughts, feelings, sometimes cooking ideas... and sometimes for gossip too...only a few messages were about the Kootu fund we were organising...'.(Thevagi, age 37)

Networking often brings a significant and strong support system for women. Most of the time, in the traditional household where rigid customs and strict societal norms were practised, the majority of these women were not permitted to move around freely in the community (Jabeen et al., 2020). Thevagi's feelings of having a peer support system (i.e. sisters, sisters-in-law, and cousin sisters) through the group formed in the aim for the Kootu fund discussion gave her immense feeling of being supported, and as a platform to share her feelings and thoughts that she cannot or could not share with her husband and children. Another participant, Sivagami, shared how the Kootu fund that she participated in has encouraged her to become an independent and empowered woman after the passing of her husband (during the pandemic season) in a road accident. About this, she further shared:

'I was devastated and loss of direction when the incident happened...he (her husband) was a big support system for me...I was merely a breakfast seller who needed to raise my three children alone...before the pandemic started, we had lots of restrictions which made it difficult to continue my breakfast selling... at that time a friend whom I knew through the Kootu fund that I had participated a few months ago became my support...she tirelessly motivated and encouraged me to expand my breakfast business into catering business...she pushed me to just jump and take the effort...from preparing the templates, planning food menu, managing the finances, everything - she did it perfectly for me...now we are partners in the catering business...'.(Sivagami, age 41) 
Women empowerment is often not being created by the push and pull factors that spark the opportunities and chances for empowerment, especially for women in traditional households (Ali, Zakuan, \& Mohammad, 2018). Sivagami's experience of being a woman who was being dependent on her husband had become a problem when her partner demised. At this time, the network that she gained through the Kootu fund was a significant factor, a strong support system in terms of emotional, financial, and social perspective. She feels empowered to develop herself along with her family due to the support system that she gained through in the form of a friend.

\section{Theme 4: Accumulation of Savings}

Savings was one factor that encouraged the women to participate in the Kootu as players or as organisers in this study. Hence $91 \%$ of participants in this study have explained that they participate in the Kootu fund intending to save money which could act as immediate savings for them, to be used whenever the need arises. Participant Sreedevi explained how the Kootu fund had become savings for her and her children:

'It's been three years I was involved as a participant in the Kootu fund....my husband would give some money for household expenses; I saved some amount of money and paid it for monthly payment for Kootu...I would say it had helped me in various ways, for it's a kind of emergency savings for me...for example when my elder daughter's marriage was fixed, it was very sudden to arrange for the money, I used my 8 months Kootu fund to buy some jewellery for her... you know this kind of situation, I only can survive if I have emergency savings like this... if not I can't sustain to the immediate needs...'.(Sreedevi, age 48)

The active participation of people in the informal savings is most likely due to lower or unstable income (Verhoef, 2001). Like Sreedevi, many socially disadvantaged women were experiencing financial deficiency since they either did not have paid work for themselves or depend on the husband for financial matters in the household. Thus, they did not have the savings for themselves in the continuation, which could provide support and assistance whenever a financial problem happens in the family. Sree Devi was able to arrange some financial assistance for her daughter's marriage using her savings vis a vis Kootu fund. In traditional households, the act of savings by women always needs to be permitted by the husband. In this study, participants admitted that they participated in the Kootu without their husband's acknowledgment as they did not allow them to play Kootu for various reasons. Anjalai explained how the husband objected to her participation in Kootu:

'I was playing Kootu for many years, since before marriage...most of the things at my mother's home is the things that I bought from the Kootu fund...it was a kind of savings to me, because in our household where money is the ultimate problem for everything...we received one income, and within that income, we need to settle everything...so where is there money to save in bank accounts...even we save we will always withdraw in two-three days because the necessity of the money is a daily issue in the households....' (Anjalai, age 43)

Formal savings are always a recurring issue in low-income households due to their sophisticated financial structure (Verhoef, 2001). Hence, it was evident that the poor people are active money savers who often save cash at home and through informal platforms (Kendall, 2012; Verhoef, 2001). Income insufficiency and limitations in terms of banking system could possibly explain the readon behind informal savings preferred by these B40 women. Individuals who have 
limited economic resources have limited liability saving for themselves (Beverly \& Sherraden, 1999). Hence, the Kootu fund helps them find a way to have savings amid the financial chaos in the households. Women in these households are often ignored for their financial needs as they are often preferred as the dependents of the husband, and no special savings were needed for themselves alone.

Constant capital or lump cash is often needed to sustain a small business or microenterprise, especially for people from poor households (Kendall, 2012). In this study, participants admitted that Kootu gave the immediate cash for them to keep the survival of their small businesses, especially after the pandemic. A participant named Kannama explained as below:

'I am selling Indian handmade silver pieces of jewellery, every month I will buy a box of that jewellery to sell to my clients...business was good when I started initially, after two months the pandemic happened...the sales were decreasing, and at one point in time I got no profit... at that time dealers were insisting on paying fully for the box... at that time the only saving I had was my Kootu, somehow I switched the turn for my Kootu with one of the players and paid off my debts to my dealer...'(Kannamma, age 45)

Raheim and Bolden (1995) asserted that self-employment has most commonly occurred among the women from poor households since the patriarchal expectation that asks them to stay home and not allow them to go for outside employment. The majority of poor people in developing countries are identified as self-employed (Fields, 2014). Like Kannamma, these poor members try to create self-employment opportunities as employment outside of the household is not accommodating due to the lack of education and other related setbacks. Thus lower-income individuals often create self-employment opportunities due to the inadequacy of employment opportunities they are facing (Fields, 2014). Hence, these women need to prepare for all the involved risks with this self-employment, such as capital and savings, to ensure the sustainability of their efforts.

\section{Conclusion}

This paper sheds light on the experiences of B40 women in Sungai Karangan, Kedah, especially those participating in the Kootu fund as the players or the organisers. This paper also presents the themes that reflect the factors that lie behind the participation of B40 women in the Kootu fund. The themes of motivation to participate economically within the setting of the household, to ease from patriarchal subordinated household roles, establish a networking system with peers around them, and accumulation of savings have emerged as the factors that motivate these women from the lower socio-economic background to participate in the Kootu fund actively. The narration of the participants disclosed that the lower socio-economic status of these women pushed them to involve in the Kootu fund as it allows them to participate and exposes them to the minimal empowerment in terms of within the spare and limitations underlined by the patriarchal system that becomes base establishment for the traditional households. Future research is certainly required to disentangle the complexities of the Kootu fund among women from various socioeconomic backgrounds and ethnicity. 


\section{Acknowledgment}

I would like to thank Lawyer Reena Nair for her kind assistance and advice for fact-checking of legal facts about the Kootu fund for this paper.

\section{References}

Acams Today (2011). Malaysia and Anti-Money Laundering. Retrieved from Acams Today website: https://www.acamstoday.org/malaysia-and-anti-money-laundering/

Ali, A. M., Zakuan, A. A. U. A., \& Mohammad, Z. Bin. (2018). The push and pull factors of women participation in trade union movements in Nigeria. Asian Journal of Multidisciplinary Studies, 6(7), 2348-7186.

Bernama. (2021). Laywers: Be cautious, Kootu funds can be illegal. Retrieved April 8, 2021, from Focus Malaysia website: https://focusmalaysia.my/mainstream/laywers-be-cautiousKootu-funds-can-be-illegal/.

Beverly, S. G., \& Sherraden, M. (1999). Institutional determinants of saving: Implications for lowincome households and public policy. The Journal of Socio-Economics, Vol. 28, pp. 457473. Elsevier.

Department of statistics (2019), Household income and expenditures: Mean monthly household gross income of top $20 \%$, middle $40 \%$ and bottom $40 \%$ of households by ethnicity, 20022019. Malaysia.

Fields, G. S. (2014). Self-employment and poverty in developing countries. IZA World of Labor, (May), 1-10. https://doi.org/10.15185/izawol.60

Jabeen, S., Haq, S., Jameel, A., Hussain, A., Asif, M., Hwang, J., \& Jabeen, A. (2020). Impacts of rural women's traditional economic activities on household economy: Changing economic contributions through empowered women in rural Pakistan. Sustainability, 12(7), 1-23. https://doi.org/10.3390/su12072731

Joremi, L., Zakaria, R. H., \& Abu Bakar, S. H. (2021). Exploring the Road Map of Young Newly Married Malay Couples in the Klang Valley on Their Quest for Financial Well-Being: a Qualitative Approach. Journal of Business and Social Development, 9(1), 13-24.

Kandiyoti, D. (1988). Bargaining with patriarchy. Gender \& Society, 2(3), 274-290.

Kendall, J. (2012). A penny saved: How do savings accounts help the poor? SSRN Electronic Journal, (2005), 1-22. https://doi.org/10.2139/ssrn.1982461

Kootu Funds (Prohibition) Act 1971 Malaysia. Retrieved from https:/www.kpdnhep.gov.my/ images/dokumen/awam/perundangan/AktaBI/19-bi-Kootu-Funds-Prohibition-Act-1971as-at-1-12-2011.pdf

Malik, S. A., \& Ayop, A. R. (2020). Solar energy technology: Knowledge, awareness, and acceptance of B40 households in one district of Malaysia towards government initiatives. Technology in Society, 63, 101416. https://doi.org/https://doi.org/10.1016/j.techsoc. 2020.101416

Omobowale, A. O. (2011). Social capital and AJO system among working class traders in Ibadan, Nigeria. The Journal of Labor and Society, 14 (September), 333-346.

Oranu, C. O., Onah, O. G., \& Nkhonjera, E. (2020). Informal Saving Group: A pathway to financial inclusion among rural women in Nigeria. Asian Journal of Agricultural Extension, Economics \& Sociology, 38(12), 22-30. https://doi.org/10.9734/AJAEES/ 2020/v38i1230484 
Ozdemir-Sarigil, B., \& Sarigil, Z. (2021). Who Is Patriarchal? The Correlates of Patriarchy in Turkey. South European Society and Politics, 1-27. https://doi.org/10.1080/13608746. 2021.1924986

Raheim, S.,\& Bolden, J. (1995). Economic empowerment of low-income women through selfemployment programs. Affilia, 10(2), 138-154.

Rani, N. S. A., Hamit, N., Das, C. A., \& Shaikh, J. M. (2011). Microfinance practices in Malaysia: from "Kootu" concept to the replication of the Grameen Bank model. J. for International Business and Entrepreneurship Development, 5(3), 269. https://doi.org/ 10.1504/jibed.2011.038033.

Sakarji, S. R., Shari, A. S., Masnieza, W., \& Mustapha, W. (2021). Entrepreneurial intention among undergraduates from B40 group: A case study in UITM Kelantan Campus. International Conferences on Language, Education, Humanities \& Social Sciences, 8290.

Satkunasingam, E. B., \& Shanmugam, B. (2006). Underground banking in Malaysia: A case study of ROSCAs. Journal of Money Laundering Control, 9(1), 99-111.

Shanmugam, B. (1991). Socio-economic development through the informal credit market. Modern Asian Studies, 25(2), 209-225.

Verhoef, G. (2001). Savings and survival in a modern African economy: Informal savings organisations and poor people in South Africa. Historia, 8 (November), November, 51942. 